\title{
PENERAPAN METODE FUZZY MAMDANI DALAM MENENTUKAN HARGA JUAL PONSEL PINTAR BEKAS (STUDI KASUS PADA KAYYIS CELLULAR DEPOK)
}

\author{
${ }^{1}$ Finata Rastic Andrari, ${ }^{2}$ Maimunah, ${ }^{3}$ Nurmala Dewi Qadarsih \\ ${ }^{123}$ Program Studi Teknik Informatika, Universitas Indraprasta PGRI \\ fina.rastic@gmail.com
}

\section{ARTICLE INFO}

Article history:

Received Nov 2021

Received in revised form 2 Nov 2021

Accepted Des 2021

Available online 24 Des 2021
This study discusses the application of fuzzy logic in determining the selling price of used cellphones with a case study on Kayyis Celluler Depok. This study was conducted to find out how to determine the selling price of used smart phones using the Mamdani fuzzy method approach. There are 4 fuzzy variables that will be modeled in this study, consisting of 3 input variables, namely the condition of the cellphone, market price, and cellphone accessories, and 1 output variable, namely the selling price of used cellphones. The inference process in the application of fuzzy operators uses the MIN implication function. Furthermore, the composition of all fuzzy outputs is performed using the max method. Then, confirmation or called defuzzification is done using the Centroid method.

Keywords: fuzzy, fuzzy logic, mamdani, smartphone's

\section{ABSTRACT}

\section{Pendahuluan}

Perkembangan teknologi saat ini membuat ponsel pintar (smartphone) menjadi kebutuhan pokok masyarakat. Bukan hanya sebagai alat komunikasi jarak jauh saja, namun ponsel pintar saat ini juga sebagai sarana pembelajaran, hiburan, bisnis, dan mata pencaharian. Berbagai manfaat ponsel pintar tersebut seakan membuat ponsel pintar menjadi wajib dimiliki oleh setiap orang. Namun, bagi sebagian masyarakat, terutama masyarakat menengah ke bawah, harga baru ponsel pintar dengan fitur yang lengkap dan memadai menjadi kendala. Maka dari itu, salah satu solusi pada kendala tersebut adalah membeli ponsel pintar bekas (second). Berbeda dengan ponsel pintar baru yang biasanya sudah ditetapkan rentang harga yang pasti, bagi penjual ponsel bekas, menentukan harga jual untuk ponsel pintar bekas tidak begitu mudah. Untuk menentukan harga ponsel bekas setidaknya harus mempertimbangkan beberapa hal seperti brand, kondisi ponsel, kelengkapan, kapasitas ponsel, lama pemakaian, harga pasaran saat ini dan lain-lain. Salah satu cara untuk untuk pendukung keputusan penentuan harga ponsel bekas, dapat menggunakan pendekatan logika fuzzy.

Logika fuzzy merupakan cabang ilmu matematika yang baru ditemukan beberapa tahun yang lalu dan memiliki konsep yang sederhana. Terdapat berbagai masalah dalam kehidupan seharihari yang erat hubungannya dengan ketidakpastian. Guna menggambarkan keadaan sehari-hari

Received November, 2021; Revised Desember , 2021; Accepted Desember, 2021 
yang tidak pasti maka muncul istilah fuzzy yang pertama kali dikemukakan oleh Zadeh pada tahun 1962 [1] . Metodologi logika fuzzy dapat diterapkan pada perangkat keras, perangkat lunak, atau kombinasi keduanya. Dalam logika klasik dinyatakan bahwa segala sesuatu bersifat biner, yang artinya adalah hanya mempunyai dua kemungkinan, "Ya atau Tidak", "Benar atau Salah", "Baik atau Buruk", dan lain lain. Oleh karena itu, semua ini dapat mempunyai nilai keanggotaan 0 atau 1. Akan tetapi, dalam logika fuzzy memungkinkan nilai keanggotaan berada di antara 0 dan 1. Artinya, bisa saja suatu keadaan mempunyai dua nilai "Ya dan Tidak", "Benar dan Salah", "Baik dan Buruk" secara bersamaan, namun besar nilainya tergantung pada bobot keanggotaan yang dimilikinya [2] .

Terdapat beberapa metode pada pendekatan logika fuzzy, yaitu Metode Tsukamoto, Metode Mamdani, dan Metode Sugeno. Pada metode Tsukamoto, setiap konsekuen pada aturan yang berbentuk IF-THEN harus dipresentasikan dengan suatu himpunan fuzzy dengan fungsi keanggotaan yang monoton [3]. Sebagai hasilnya, outputsil inferensi dari tiap-tiap aturan diberikan secara tegas berdasarkan $\alpha$ predikat. Pada metode Mamdani, baik input maupun output sistem berupa himpunan fuzzy. Sedangkan pada metode Sugeno, penalaran yang dilakukan hampir sama dengan penalaran Mamdani, yang berbeda adalah pada outputnya [4]. Output pada penalaran Sugeno tidak berupa himpunan fuzzy, melainkan berupa konstanta atau persamaan linear [5]. Pada penelitian ini, peneliti menggunakan logika fuzzy dengan penalaran metode Mamdani.

\section{Metode Penelitian}

Penelitian ini merupakan penelitian eksperimen yaitu merancang sebuah model untuk menentukan harga jual ponsel pintar bekas dengan pendekatan logika fuzzy. Pada penelitian ini data diperoleh dari wawancara dengan pemilik Kayyis Celluler. Selain itu dilakukan juga wawancara serta studi literatur untuk mengetahui faktor-faktor yang mempengaruhi harga jual ponsel pintar pada Kayyis Celluler.

\section{Hasil Pembahasan}

Beberapa tahapan yang dilakukan untuk merancang model untuk menentukan harga jual ponsel pintar bekas adalah :

1. Pembentukan variabel input dan variabel output himpunan fuzzy.

2. Penetapan aturan (rule) untuk penetapan harga jual ponsel bekas pada Toko Kayyis Celluler.

3. Aplikasi operator fuzzy.

4. Komposisi aturan.

5. Penegasan (Defuzzy).

Pada tahap ini merupakan penetapan variabel input maupun variabel output yang terdiri dari satu atau lebih himpunan fuzzy. Variabel output dalam penelitian ini adalah harga jual ponsel pintar bekas. Sedangkan untuk penentuan variabel-variabel input dalam penelitian ini berdasarkan wawancara dengan pemilik Toko Kayyis Celluler dan studi literatur. Beberapa pertimbangan dalam menentukan harga jual ponsel bekas antara lain, merk ponsel, kondisi fisik, kualitas ponsel, spesifikasi ponsel, kapasitas memori, harga pasaran, kelengkapan aksesoris bawaan ponsel, lama pemakaian ponsel, dan tahun dikeluarkan ponsel. Berdasarkan hasil wawancara tersebut, peneliti mengambil tiga variabel input yang paling berpengaruh terhadap harga jual ponsel bekas yaitu kondisi fisik dan spesifikasi ponsel, harga beli pasaran, dan kelengkapan ponsel.

Terdapat 4 variabel fuzzy yang akan dimodelkan pada penelitian ini, terdiri dari 3 variabel input dan 1 variabel output, yaitu :

- Kondisi Fisik dan Spesifikasi Ponsel 
Variabel ini mencakup kondisi fisik ponsel bekas seperti goresan pada ponsel, layar ponsel, kondisi baterai, dan tombol ponsel yang masih berfungsi atau tidak. Selain itu, variabel ini juga mencakup speifikasi ponsel tersebut, yaitu mempertimbangkan brand dari ponsel tersebut, kapasitas memori, dan kondisi kamera. Variabel kondisi fisik dan spesifikasi ponsel bekas terdiri dari 3 himpunan fuzzy, yaitu : KURANG, CUKUP, BAGUS. Untuk selanjutnya variabel ini disebut variabel kondisi.

- Harga beli

Dalam penelitian ini, variabel harga beli ponsel merupakan harga pasaran ponsel dengan merk dan tipe yang sama. Harga pasaran yang dimaksud adalah harga pasaran ponsel baru saat menjual kembali ponsel tersebut, bukan harga saat pengguna membeli ponselnya. Hal ini dikarenakan ponsel merupakan alat elektronik yang harganya selalu mengalami penurunan seiring dengan berjalannya waktu dan berkembangnya model dan teknologi baru. Ponsel bekas yang diperjualbelikan di Kayyis Selluler merupakan ponsel standar untuk kalangan menengah ke bawah, sehingga domain pada variabel ini dibatasi hingga Rp 5.000.000. Variabel ini terdiri dari 3 himpunan fuzzy, yaitu : RENDAH, STANDAR, TINGGI. Untuk selanjutnya variabel ini disebut variabel harga pasaran.

- Kelengkapan Ponsel

Kelengkapan ponsel juga merupakan variabel penting dalam menentukan harga jual ponsel bekas tersebut. Kelengkapan ponsel mencakup seluruh aksesoris bawaan dalam ponsel tersebut seperti charger, dus asli ponsel, kartu garansi dan lainnya. Variabel ini terdiri dari 3 himpunan fuzzy, yaitu : KURANG, CUKUP, LENGKAP. Untuk selanjutnya variabel ini disebut variabel kelengkapan.

- Harga Jual

Variabel ini merupakan variabel output yang terdiri dari 3 himpunan fuzzy, yaitu RENDAH, STANDAR, TINGGI. Domain pada variabel harga jual dibatasi hingga Rp 5.000.000.

Domain dan himpunan fuzzy variabel input dan output pada penelitian ini dapat dilihat pada Tabel 1.

Tabel 1. Himpunan Fuzzy pada kasus Harga Jual Ponsel Bekas

\begin{tabular}{ccccc}
\hline Fungsi & Variabel & Himpunan & Semesta & Domain \\
& & Fuzzy & Pembicaraan & \\
\hline Input & Kondisi & KURANG & {$[0,100]$} & {$[0,60]$} \\
& & CUKUP & & {$[50,80]$} \\
& BAGUS & & {$[70,100]$} \\
& Harga & RENDAH & {$[0,5.000]$} & {$[0,2.750]$} \\
& Pasaran & STANDAR & & {$[1.500,4.500]$} \\
& (dalam ribu) & TINGGI & & {$[3.500,5.500]$} \\
& Kelengkapan & KURANG & {$[0,100]$} & {$[0,40]$} \\
& & CUKUP & & {$[30,80]$} \\
& & LENGKAP & {$[65,100]$} \\
Output & RENDAH & {$[0,5.000]$} & {$[0,2.500]$} \\
& Harga Jual & STANDAR & & {$[1.500,4.000]$} \\
& (dalam ribu) & TINGGI & & {$[3.000,5.000]$} \\
\hline
\end{tabular}

a. Variabel Kondisi

Representasi variabel kondisi dapat dilihat pada Gambar 1. Untuk himpunan fuzzy KURANG dan BAGUS menggunakan kurva berbentuk bahu. Sedangkan untuk 
himpunan fuzzy CUKUP menggunakan kurva segitiga. Fungsi keanggotaan variabel kondisi adalah sebagai berikut :

$$
\begin{aligned}
& \mu_{\text {KURANG }}[a]=\left\{\begin{array}{cc}
\frac{60-a}{60} & a \leq 60 \\
0 & a>60
\end{array}\right. \\
& \mu_{\text {CUKUP }}[a]=\left\{\begin{array}{cc}
\frac{0-50}{15} & a \leq 50 \text { atau } a \geq 80 \\
\frac{80-a}{15} & 50 \leq a<65
\end{array}\right. \\
& \mu_{\text {BAGUS }}[a]=\left\{\begin{array}{cc}
0-70 & a<70 \\
\frac{a-70}{30} & a \geq 70
\end{array}\right.
\end{aligned}
$$

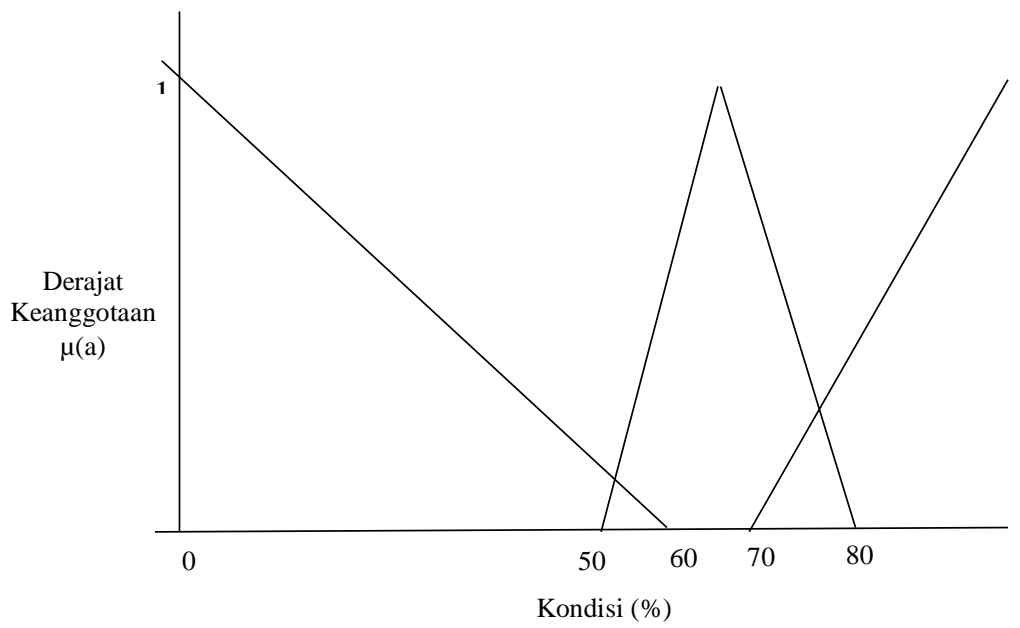

Gambar 1 Representasi variabel kondisi.

b. Variabel Harga Pasaran

Representasi harga pasaran menggunakan kurva segitiga untuk ketiga himpunan fuzzy yaitu RENDAH, STANDAR, dan TINGGI. Representasi tersebut dapat dilihat pada Gambar 2. Fungsi keanggotaan variabel harga pasaran didefinisikan sebagai berikut :

$$
\begin{aligned}
& \mu_{\text {RENDAH }}[b]=\left\{\begin{array}{cc}
\frac{2750-b}{2750} & b \leq 2.750 \\
0 & b \geq 2.750
\end{array}\right. \\
& \mu_{\text {STANDAR }}[b]=\left\{\begin{array}{cc}
\frac{b-1500}{2000} & b \leq 1500 \text { atau } b \geq 4500 \\
\frac{4500-b}{1000} & 1500<b \leq 3500
\end{array}\right. \\
& \mu_{\text {TINGGI }}[c]=\left\{\begin{array}{cc}
0 & 3500<b \leq 4500 \\
\frac{c-3500}{2000} & b \geq 3500
\end{array}\right.
\end{aligned}
$$




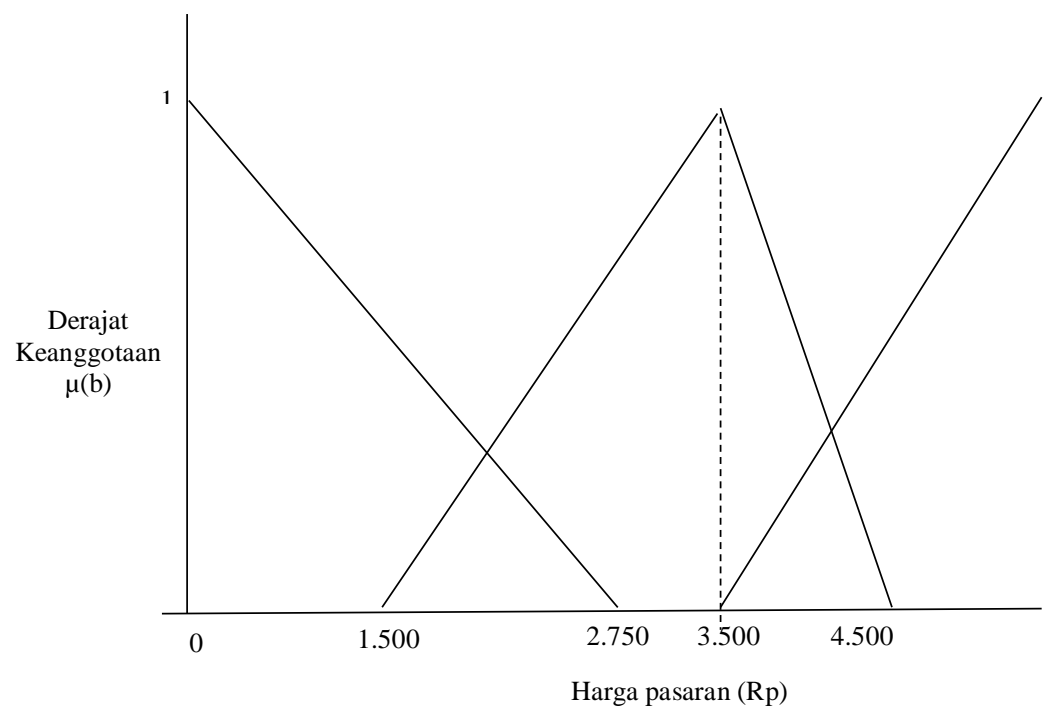

Gambar 2 Representasi variabel harga pasaran.

c. Variabel Kelengkapan

Representasi variabel kelengkapan dapat dilihat pada Gambar 3. Untuk himpunan fuzzy KURANG dan LENGKAP menggunakan kurva berbentuk bahu. Sedangkan untuk himpunan fuzzy CUKUP menggunakan kurva segitiga. Fungsi keanggotaan variabel kondisi adalah sebagai berikut :

$$
\begin{gathered}
\mu_{\text {KURANG }}[c]=\left\{\begin{array}{cc}
\frac{40-c}{40} & c<40 \\
0 & c \geq 40
\end{array}\right. \\
\mu_{\text {CUKUP }}[c]=\left\{\begin{array}{cc}
0 & c \leq 30 \text { atau } c \geq 80 \\
\frac{c-30}{25} & 30<c \leq 55 \\
\frac{80-c}{25} & 55<c \leq 80
\end{array}\right. \\
\mu_{\text {LENGKAP }}[c]=\left\{\begin{array}{cc}
0 & c \leq 65 \\
\frac{c-65}{35} & c>65
\end{array}\right.
\end{gathered}
$$

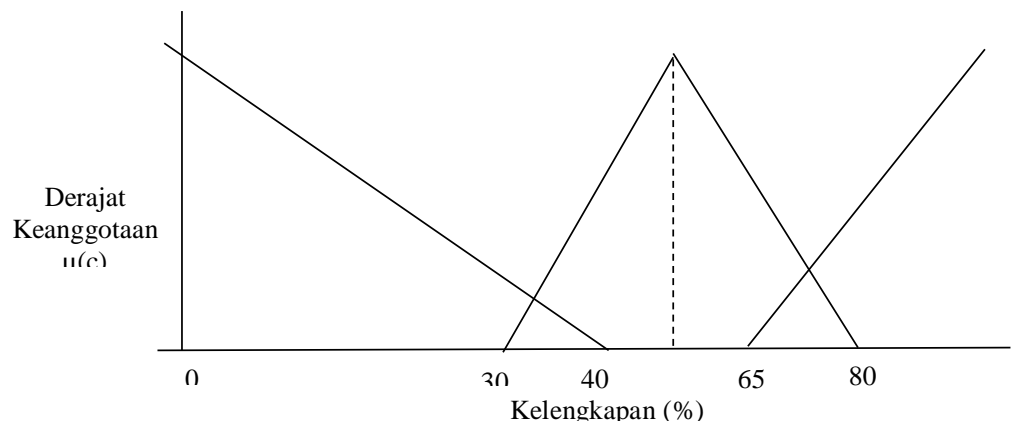

Gambar 3 Representasi variabel kelengkapan.

d. Variabel Harga Jual 
Representasi harga pasaran menggunakan kurva segitiga untuk ketiga himpunan fuzzy yaitu RENDAH, STANDAR, dan TINGGI. Representasi tersebut dapat dilihat pada Gambar 4. Fungsi keanggotaan variabel harga pasaran didefinisikan sebagai berikut :

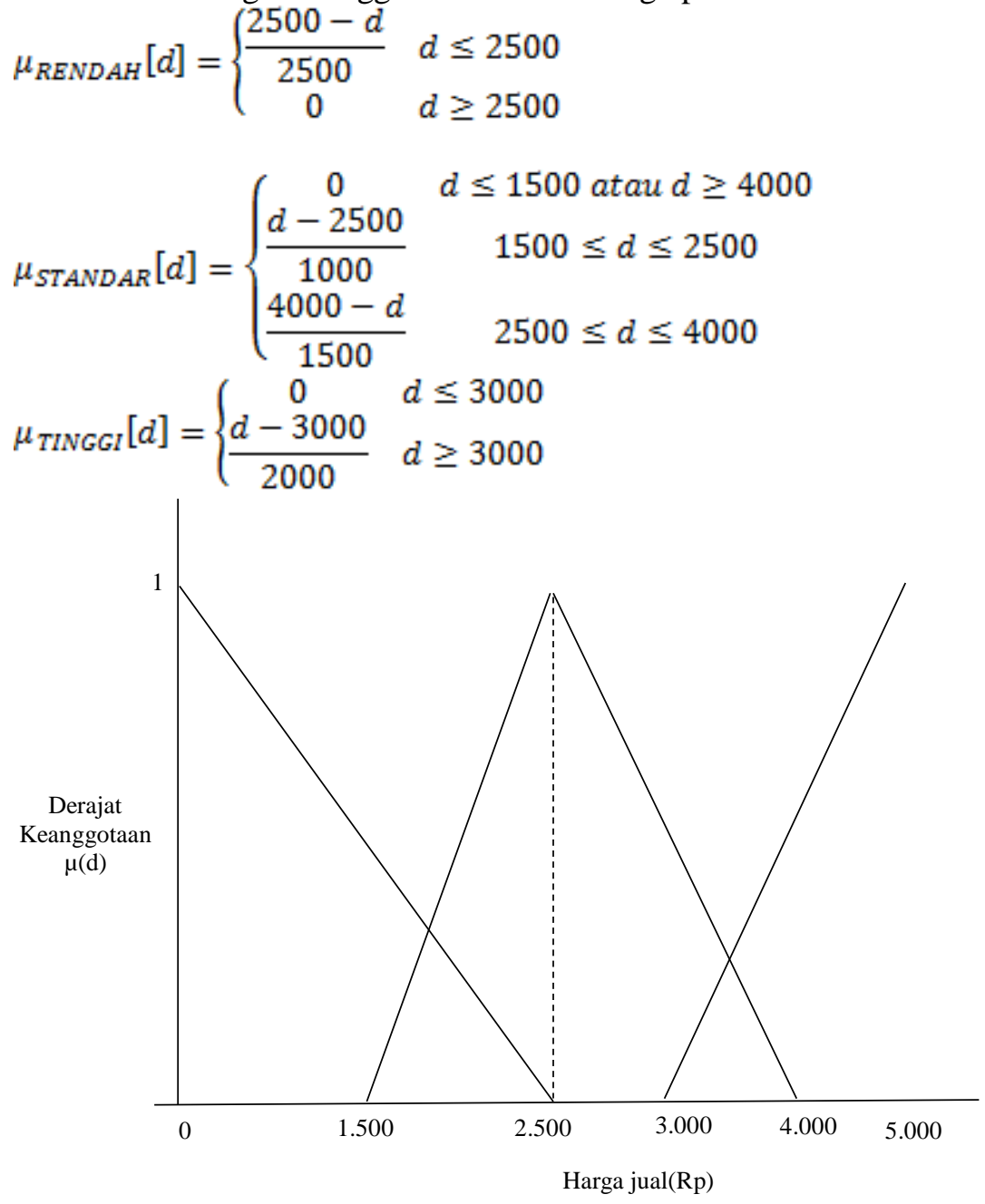

Gambar 4 Representasi variabel harga jual.

\section{Penerapan aturan penetapan harga jual ponsel bekas pada Toko Kayyis Celluler.}

Pembentukan aturan pada penelitian ini berdasarkan studi literatur dan wawancara dengan pemilik toko Kayyis Celluler dan studi literatur. Aturan yang digunakan menggunakan logika IF-THEN. Berikut aturan yang digunakan pada penelitian ini :

[R1] jika kondisi KURANG maka harga jual RENDAH.

[R2] jika harga pasaran RENDAH maka harga jual RENDAH.

[R3] jika kondisi CUKUP, harga pasaran STANDAR, dan kelengkapan KURANG maka harga jual RENDAH.

[R4] jika kondisi CUKUP, harga pasaran STANDAR maka harga jual STANDAR.

[R5] jika kondisi CUKUP, harga pasaran TINGGI maka harga jual TINGGI.

[R6] jika kondisi BAGUS, harga pasaran STANDAR, dan kelengkapan KURANG maka harga jual RENDAH.

[R7] jika kondisi BAGUS, harga pasaran STANDAR maka harga jual STANDAR. 
[R8] jika kondisi BAGUS, harga pasaran TINGGI, dan kelengkapan KURANG maka harga jual RENDAH.

[R9] jika kondisi BAGUS, harga pasaran TINGGI, dan kelengkapan CUKUP maka harga jual STANDAR.

[R10] jika kondisi BAGUS, harga pasaran TINGGI, dan kelengkapan LENGKAP maka harga jual TINGGI.

\section{Komposisi aturan dan penegasan (Defuzzy).}

Proses inferensi dalam aplikasi operator fuzzy menggunakan fungsi implikasi MIN. Selanjutnya, komposisi semua output fuzzy dilakukan dengan menggunakan metode max. Kemudian, penegasan atau disebut defuzzifikasi dilakukan dengan menggunakan metode Centroid. Pada metode ini, solusi crisp diperoleh dengan cara mengambil titik pusat daerah fuzzy. Secara umum dirumuskan :

$z=\frac{\int_{Z} z \mu(z) d z}{\int_{z} \mu(z) d z}$

\subsection{SIMULASI FUZZY INFERENCE SYSTEM MAMDANI}

Dalam penelitian ini, simulasi penetapan harga jual pnsel bekas menggunakan software Matlab dengan langkah sebagai berikut :

1. Membuat variabel input dan output dan fungsi keanggotaannya

Berdasarkan himpunan fuzzy yang telah ditentukan pada Tabel 5.1, diperoleh fungsi keanggotaan dari variabel input dan output. Variabel input diantaranya adalah kondisi, harga pasaran, dan kelengkapan. Sedangkan variabel output adalah harga jual ponsel bekas. Beikut tampilan himpunan fuzzy variabel input dan output yang berturut-turut ditampilkan pada Gambar 5, Gambar 6, Gambar 7, dan Gambar 8.

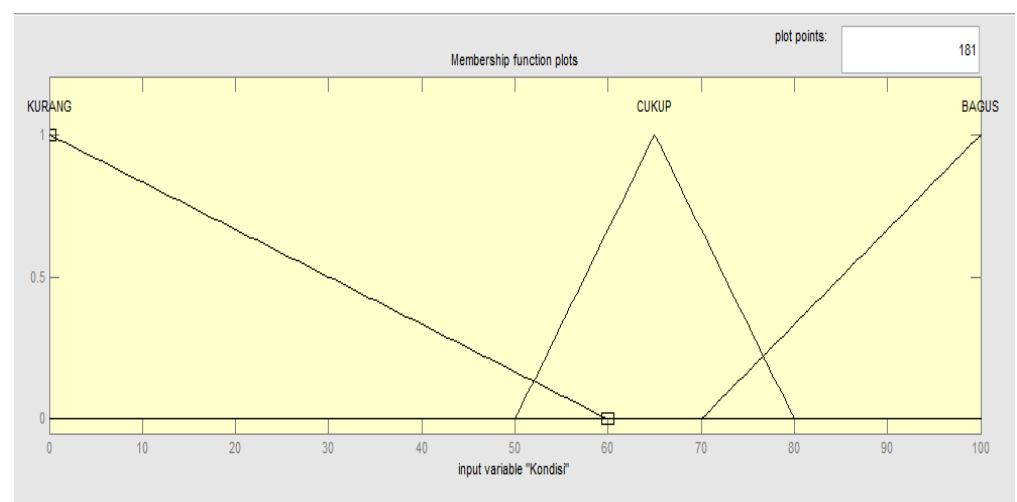

Gambar 5 Himpunan fuzzy variabel kondisi 


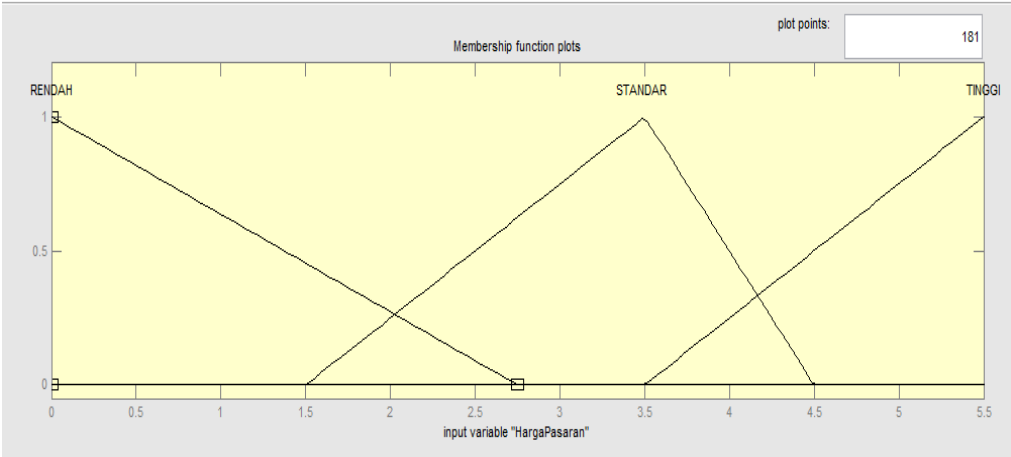

Gambar 6 Himpunan fuzzy variabel Harga Pasaran

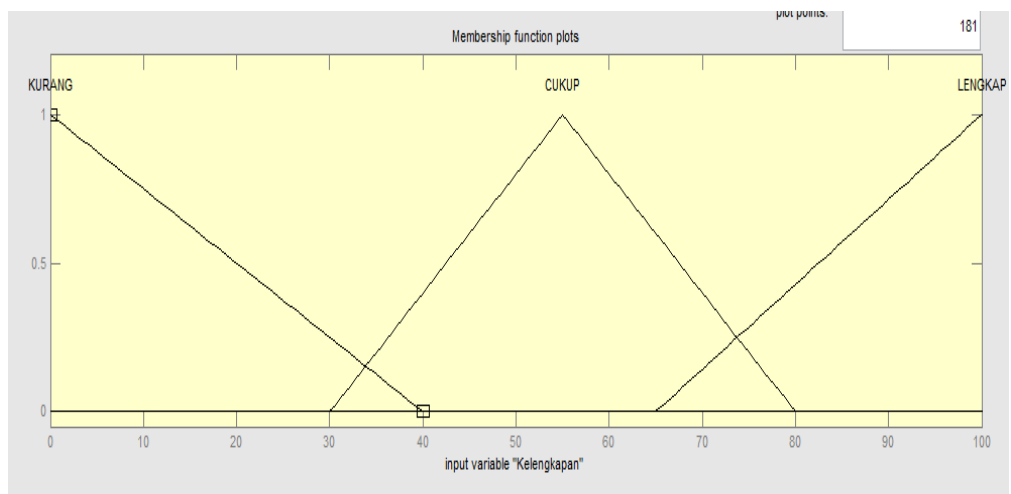

Gambar 7 Himpunan fuzzy variabel Kelengkapan

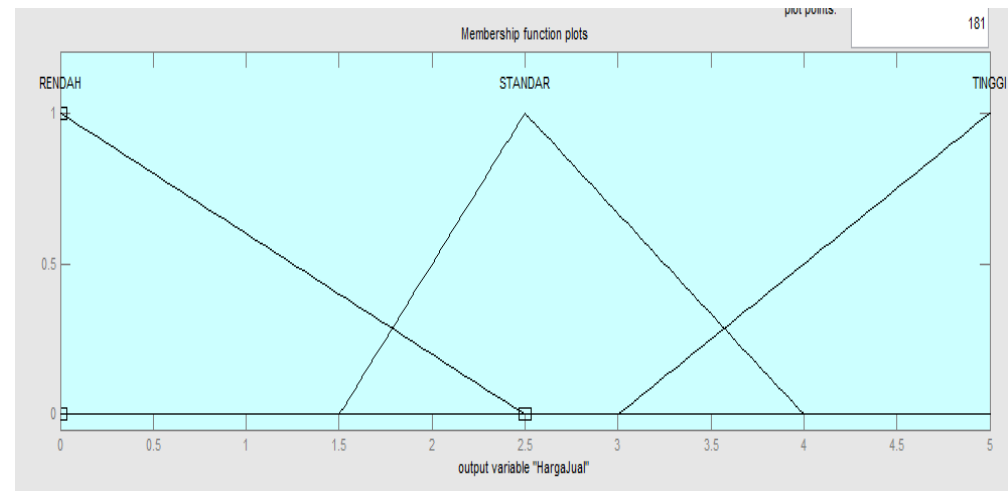

Gambar 8 Himpunan fuzzy variabel output : Harga Jual Ponsel Bekas

2. Membuat aturan fuzzy

Pembentukan aturan pada penelitian ini berdasarkan studi literatur dan wawancara dengan pemilik toko Kayyis Celluler dan studi literatur. Aturan yang digunakan menggunakan logika IF-THEN. Seperti yang dibahas sebelumnya, terdapat 10 aturan dengan penghubung antar variabel input menggunakan operator AND.

3. Defuzzyfikasi

Defuzzyfikasi pada penelitian ini menggunakan metode centroid. Solusi crisp diperoleh dengan cara mengambil titik pusat pada daerah fuzzy. Tampilan defuzzyfikasi pada software dapat dilihat pada Gambar 9. Output diperoleh dengan cara memasukkan data simulasi pada kolom input. Pada Gambar 5.9, contoh input yang dimasukkan adalah [90 4.5 100] yang artinya input variabel kondisi sebesar 90\%, harga pasaran sebesar Rp

JURNAL ILMIAH KOMPUTER GRAFIS Vol. 14, No. 2, Desember 2021 : 253-262 
4.500.000 dan kelengkapan sebesar 100\% maka akan menghasilkan output harga jual ponsel bekas sebesar Rp 4.240.0000.

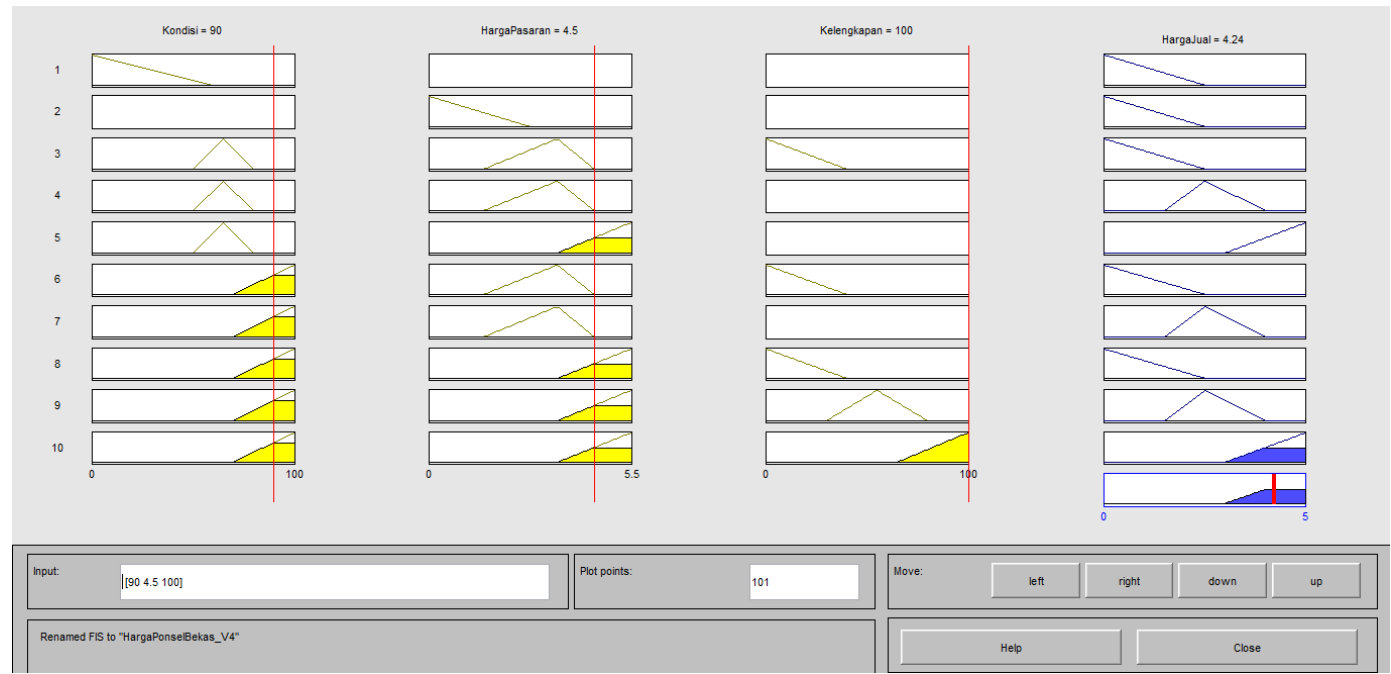

Gambar 9 Defuzzyfikasi metode Mamdani.

Berikut adalah beberapa output perkiraraan harga jual ponsel bekas yang dihasilkan oleh metode mamdani dengan memasukan beberapa nilai input. Pada Tabel 2 terlihat harga ponsel bekas yang dihasilkan oleh sistem mamdani pada penelitian ini cukup sebagai pertimbangan pengambilan keputusan dalam menentukan harga jual ponsel bekas di Kayyis Selluler Depok.

Tabel 2 Output Harga jual ponsel bekas dengan metode Mamdani

\begin{tabular}{ccccc}
\hline No. & $\begin{array}{c}\text { Kondisi } \\
(\%)\end{array}$ & $\begin{array}{c}\text { Harga Pasaran } \\
\text { (dalam ribu) }\end{array}$ & $\begin{array}{c}\text { Kelengkapan } \\
(\%)\end{array}$ & $\begin{array}{c}\text { Harga Jual } \\
\text { Ponsel Bekas } \\
\text { (dalam ribu) }\end{array}$ \\
\hline 1 & 90 & 4.500 & 100 & 4.240 \\
2 & 80 & 1.500 & 90 & 0.981 \\
3 & 95 & 3.000 & 90 & 2.670 \\
4 & 50 & 2.500 & 95 & 1.140 \\
5 & 70 & 3.500 & 95 & 2.680 \\
\hline
\end{tabular}




\section{Kesimpulan}

Berdasarkan hasil eksperimen yang dilakukan penelitian mengenai Penerapan Metode Fuzzy Mamdani dalam Menentukan Harga Jual Ponsel Pintar Bekas, maka dapat diambil kesimpulan bahwa metode fuzzy Mamdani dapat diterapkan dalam menentukan harga jual ponsel bekas dengan variabel output adalah harga jual ponsel bekas, serta variabel inputnya, yaitu kondisi ponsel bekas, harga pasaran ponsel, dan kelengkapan ponsel bekas. Permasalahan pada penelitian ini masih menggunakan variabel umum, yaitu kondisi ponsel bekas, harga pasaran ponsel, dan kelengkapan ponsel bekas. Sehingga penelitian ini masih dapat dikembangkan dengan menambah variabel input yang lebih kompleks, seperti lama pemakaian ponsel, tahun keluaran ponsel, dan lain sebagainya. Selain itu, penelitian ini hanya membahas penerapan metode fuzzy Mamdani, untuk penelitian berikutnya dapat digunakan metode fuzzy Sugeno dan Tsukamoto untuk membandingkan metode mana yang lebih akurat dalam permasalahan ini.

\section{Daftar Pustaka}

[1] Astuti, D. P. P., \& Mashuri. Penerapan Metode Fuzzy Sukamoto dan Fuzzy Sugeno dalam Penentuan Harga Jua Sepeda Motor. UNNES Journal of Mathematics, 9(2), 74-78, 2020.

[2] Minarni, \& Aldyanto, F. Prediksi Jumlah Produksi Roti Menggunakan Metode Logika Fuzzy (Studi Kasus : Roti Malabar Bakery). Jurnal TEKNOIF, 4(2), 59-65, 2016.

[3] Kusumadewi, S., \& Purnomo, H. Aplikasi Logika Fuzzy (2nd ed.). Yogyakarta: Graha Ilmu, 2010.

[4] Kusumadewi, S. Analisis Desain Sistem Fuzzy Menggunakan Tool Box Matlab (1st ed.). Yogyakarta: Graha Ilmu, 2002.

[5] Pusadan, M. Y. Pemograman Matlab Pada Sistem Pakar Fuzzy. Yogyakarta: deepublish, 2014. 